\title{
ERP SYSTEM IMPLEMENTATION IN LATVIAN MANUFACTURING AND CONSTRUCTION COMPANY
}

\author{
Andrejs Tambovcevs \\ Faculty of Computer Science and Information Technology, Riga Technical University, \\ Mezha street 1/7, room 213, LV-1048 Riga, Latvia \\ E-mail:ata2000@inbox.lv
}

Received 02 September 2010; accepted 05 November 2011

\begin{abstract}
The enterprise resource planning (ERP) software market has been growing at a very fast pace over the last few years and has been predicted to keep growing rapidly in the long term. ERP systems have the potential to integrate seamlessly organizational processes using common shared information and data flows. Enterprises recently tend to implement their new enterprise information systems like ERP system in order to gain their competitive advantages and bring up their business efficiency, but the efficiency gained from this new implementation is not quite clear and is difficult to be identified. This paper presents a case study of ERP systems implementation in international construction materials procurement and purchasing company in Latvia. Specifically, this paper briefly described the business processes involved in the manufacturing and construction company and illustrated how ERP systems could be implemented and the efficiency of management system consequently enhanced. For an international company, the headquarters' successful experience can provide a guideline to assist the local office to implement new system effectively and efficiently. ERP information system supports manufacturing process and construction object related information. This paper also argues that ERP systems are an increasingly important source of organizational change with major implications for the organization and management of work.
\end{abstract}

Keywords: enterprise resource planning (ERP), ERP system, management systems, construction, manufacturing.

Reference to this paper should be made as follows: Tambovcevs, A. 2012. ERP system implementation in Latvian manufacturing and construction company, Technological and Economic Development of Economy 18(1): 67-83.

JEL Classification: L61, L74, L86. 
A. Tambovcevs. ERP system implementation in Latvian manufacturing ...

\section{Introduction}

To achieve business targets and maintain long-term competitive advantage, real-time and precise operation flows must be integrated within the organization, and information technology and limited company resources must be fully utilized as well.

Information technology has been a force multiplier for organizations desirous of gaining a competitive edge in a global business environment. The need to share large quantities of data effectively and efficiently between suppliers, customers, geographically dispersed units, and internal functional departments necessitated the development of integrated information systems (Monk, Wagner 2009: 4). In this light, many enterprises have devoted themselves to implementing enterprise resource planning (ERP) systems. Enterprise resource planning systems are examples of the most strategic tools a business can employ. ERP is a software package that attempts to integrate all departments and functions of a company onto a single computer system that can serve all different departments' needs. ERP systems have transformed the way organizations go about the process of providing information systems. They help integrate company operations by creating a computing environment that includes a central database for sales and marketing, production and materials management, accounting and finance, and human resource functional business data (Monk, Wagner 2009: 27). The functional areas are further divided into modules that comprise the integrated information system environment to meet the demands of the company's strategic objectives and goals.

Throughout the 1990s, most large industrial companies installed ERP systems; that is, massive computer applications allowing a business to manage all of its operations (finance, requirements planning, human resources, and order fulfillment) on the basis of a single, integrated set of corporate data. ERP promised huge improvements in efficiency; for example, shorter intervals between order and payments, lower back-office staff requirements, reduced inventory, and improved customer service. Every year companies invest a lot of money in the implementation of ERP systems. The ARC Advisory Group estimates that the total ERP market in 2006 was $\$ 18.4$ billion and foresaw an annual growth of the market to the level of $6.7 \%$. It means that by 2011 the value of the market will have reached $\$ 24$ billion (Klos, Krebs 2008). Encouraged by these possibilities, businesses around the world invested some $\$ 300$ billion in ERP during the decade (Dorien, Malcolm 2000; Everdingen et al. 2000).

Over the past few years, limited research has been conducted about ERP implementation issues: mainly case studies in individual organizations have been reported. Since 2000, numerous reviews on ERP projects have been undertaken in Europe or in USA. Some are quantitative or qualitative surveys, other are based on case studies. A major problem with such ERP case studies is that very few implementation failures challenges resulting to these failures have been recorded in the literature, and thus the reasons why implementations fail are not known to practitioners and researchers. That is a motivation toward conducting empirical studies to explore challenges, benefits, barriers and costs of ERP systems implementation.

The most of studies focus mainly on ERP implementation and how to increase the success rate of implementing ERP systems. ERP implementation projects, their impact and success factors was described by Davenport (2000), Krumbholz et al. (2000), Adam and O’Doherty (2000), Mark and van Han (2000); Markus et al. (2000); Chiara (2001); Huang and 
Kim (2002), Rajagopal (2002), Umble, E. J. and Umble, M. M. (2002), Loh and Koh (2004), Dowlatshahi (2005), Soja (2006), Sun et al. (2005), Verville et al. (2005), Woo (2007). Ehie and Madsen (2005) listed business process re-engineering as one of three crucial factors for ERP project success. The importance of considering ERP success at multiple points in time was determined by Kim et al. (2005) and Ahitur et al. (2002). ERP implementation model or methodology in case-based studies was investegeted by Voordijk et al. (2003), Anne and Shanks (2000), Scheer and Frank (2000), Motwani et al. (2002), Chang (2002). Huang et al. (2001) investigated relationships of an organization's ERP system and a knowledge management system; it impacts on efficiency and flexibility. Olhager and Selldin (2003) from November 2000 to January 2001 surveyed ERP implementations in 511 Swedish manufacturing firms, concerned with ERP system penetration, the pre-implementation process, implementation experience, ERP system configuration, benefits and future directions (response rate of $32.7 \%$ ). Tsai et al. (2012) survey examined the ERP implementation experiences of the top 5000 largest corporations in Taiwan to explore the status of their ERP implementation. Verville et al. (2007) looks at the process of planning in the acquisition of ERP systems studing four organization's planning process.

Construction is the process of transforming materials and permanent equipment into a finished facility. Compared with a manufacturer who has production facilities, a construction company has different resources since several parties including the owner, designer; contractor, subcontractor, and supplier are involved in delivering the facility. With the development of new technologies such as the drawing tool, Internet, and wireless instruments, many companies now consider technological improvements an essential part of their long-term competitive strategy, and consequently try to apply these technologies. Computer technology has brought about many benefits in helping the construction industry meet increasingly complex challenges. It has achieved a wide range of successful applications at the project level such as engineering design, project estimating, scheduling, planning and control, and integrated project management. Since its applications in the construction business are still very much limited to areas such as accounting, costing, and financing functions, research is essential in exploring a wider range of usage of computers to improve the efficiency of construction business operations and management.

There are many research studies and efforts on selection and implementation of 'generic' ERP systems in the construction industry, for example, Acikalin et al. (2009), Chung et al. (2008, 2009), Shi and Halpin (2003), Yang et al. (2007). Van Nieuwenhuyse et al. (2011) suggest to develop an advanced resource planning module, that provides additional intelligence to ERP systems at the midterm planning level. The ARP enables planners to capture relationships among variability and uncertainty on the one hand and capacity utilization, lead time, and customer service on the other hand.

Companies that use a generic ERP system often need to configure and customize it to support their own business needs. This configuration and customization process usually takes significant time, effort, and investment. In addition, most ERP systems on the market are mainly targeted to large companies with a stable supply chain, while construction supply chains are unstable project-based in nature. 
This paper presents case-study results of ERP systems implementation in international construction materials procurement and purchasing company in Latvia. The research problem originates from everyday activities of manufacturing and construction company $\mathrm{X}$, which is trying to improve project progress tracking and resource management in multi-project environment.

\section{Enterprise resource planning systems}

ERP system is an integrated set of programs that provides support for core organizational activities such as manufacturing and logistics, finance and accounting, sales and marketing, human resources, supply chain, and customer information. An ERP system helps the different parts of an organization share data and knowledge, reduce costs, and improve management of business processes.

The evolution of the ERP concept started in the early 1960s with 'inventory control packages', and then with "material requirements planning: MRP", followed by 'manufacturing resource planning: MRP II'.

ERP systems can be categorized by price (license fee, and implementation expenses). Industry-specific versions of large ERP systems are available for many industries. Usually, big businesses need large ERP systems applications. Large ERP systems are SAP, Oracle, PeopleSoft and JD Edwards and other. Medium size businesses go for medium size ERP. The midrange ERP applications include QAD, Microsoft's Navision, iScala etc. Small, shoestring ERP applications are available for even the smallest enterprise. Smaller systems include popular low cost business applications that are complete but simplified systems.

\subsection{Enterprise resource planning function}

The enterprise resource planning intends to support one time entry of information at the point where it is created and make it available to all the systems that need it. Application integration is a methodology for moving data from application to application without reentry by integrating these applications. Thus, the data can be stored in hundreds of tables that are all part of one common database shared by multiple users from multipleplaces and departments for multiple purposes. This common database for the entire enterprise is referred to as internal integration (Back, Bell 1995). External integration means connecting the computer network of an enterprise or an organization with the computer networks of business partners such as clients and suppliers for information sharing and exchange. The enterprise resource planning also enables automation; thus, any benefit attributable to automation can be credited to ERP. Automation in materials management improves labour productivity by providing good documentation (Bell, Stukhart 1986).

Reengineering of business processes goes hand-in-hand with the implementation of an ERP (Subramoniam, Tounsi 2009). Processes represent "the activity and information flows necessary to accomplish a particular task or set of tasks” (O’Leary 2000: 35). Processes can differ across organizations as well as within organizations. One of the purported primary benefits of ERP systems is the standardization of these processes across the organization providing centralization of such processes. To accommodate coordination, ERP companies generally 
standardize their chart of accounts and other categorization schemes along with reports and reporting procedures at the same time they standardize their operational procedures. Common practices provide the capability of integrating across various system applications, thus facilitating the integration of corporate information systems. Change management is also critical for successful ERP system implementation. It also considered as main obstacles for successful ERP implementation (Wood 2010).

Functions of ERP system can be described as follows:

- The "objective" of an ERP system is to "automate" the business processes of the enterprise, of course, for the benefits resulting from this automation; that is, supporting "e-business implementation" leading to better enterprise performance.

- The "functions" of an ERP system, which are associated with the "supply chain" of the enterprise, including both its primary business activities and its support activities, are "integrated across the enterprise" leading to higher efficiency.

- The "architecture" of an ERP system is of "modular" construction that is of dynamic structure, which makes it flexible to modifications and expansions.

Accordingly, an ERP system is a combination of the following functions: application integration, which enables data to be communicated automatically among applications; internal integration, which enables data to be stored centrally in an integrated database to be accessed by anyone in the organization who needs it; external integration, which enables the internal organizational network to be connected to all or most business partners outside the organizational boundary; and automation enabled by the applications themselves. Thus, the transformation from a non-ERP system into an ERP system is performed through these ERP functions. While all data of all functional departments reside in a central database, functional groups use the applicable software for their departments. The enterprise resource planning uses wide area networks (WANs) that enable the coordination of company activities globally. Likewise, ERP can provide an integrated working environment in its major business management functions.

\subsection{Enterprise resource planning implementation}

Companies implement ERP because of the tremendous benefits derived from the enterprise integration of processes and applications such as information visibility, business integration, integration of applications residing in different departments, and standardization of processes (Fryer 1999). In particular, construction companies use ERP systems to improve responsiveness in relation to customers, strengthen supply chain partnerships, enhance organizational flexibility, improve decision-making capabilities, shorten project completion time, and lower costs. Nevertheless, the construction industry has some uniqueness that should be taken into consideration by ERP vendors. The construction industry is highly fragmented, with specialized segments requiring specialized systems. It is also driven by different projects.

The problems that led to the failure of ERP implementation can be grouped into the categories of human / organizational (e.g. lack of strong and committed leadership), technical (e.g. problems in software customization and testing, and lack of technically knowledgeable staff) and economic (e.g. lack of economic planning and justification) (Sarker, Lee 2003). 
O'Leary (2000) described ERP implementation problems too, especcialy focusing on technical and organizational problems.

The author discovered difficulties in ES implementations and suggest dividing them into the following categories: economic, technical, organizational, and social.

- Economic problems concern issues related to the company's economic condition and they are usually connected with scarce financial resources and high costs incurred.

- Technical problems refer to the particular system solution and surrounding IT infrastructure. They are also connected with problems of information processing. Problems of technical notion "arise largely because of information processing technology" (O’Leary 2000).

- Organizational problems concern issues related to the aligning of corporate organizational structure and its procedures to an enterprise system's needs. These problems are derived from an environment in which the system is chosen and implemented (O'Leary 2000). This group also covers issues related to the organization and execution of an implementation project.

- Social problems are connected with the people involved in a project and their attitudes. They relate to multiple stakeholders from an organization introducing an ES package as well as the system provider's representatives.

In general, top management can customize and modify ERP implementation to incorporate non-standard and company specific processes where the derived competitive advantage and differentiation aspects are clearly demonstrated. This implementation strategy may or may not be cost effective and may pose additional challenges, e.g. maintaining adequate skills and documentation and/or encouraging ERP vendors to incorporate modifications in the future upgrades.

\section{Case descriptions}

\subsection{General information about the studied company}

Prefabrication of building components at a remote facility is shown to save space for material storage on site, assures better quality control of part production, reduces waste and enables reengineered and more efficient supply chain management. However, industrialization of the construction process requires a high level of automatization. At this point, the construction industry faces many problems, especially as far as handling of information and integration of data and information systems are concerned.

The Company P supplies metal-based components, systems and integrated systems to the construction and engineering industries. The company has a wide selection of metal products and services. Company P has operations in 27 countries and employs 11.800 people. Net sales in 2009 totalled EUR 1.95 billion, in 2010 - 2.41 billion, but in 2011 - 2.797 billion euro.

The studied company (subsequently termed company $\mathrm{X}$ ) is a middle-size manufacturing and construction company. It is a subsidiary company of Company P in Latvia. The company was established in 1995s and had a staff of about 110. In the construction industry in Latvia, the studied company was ranked among the top five construction firms according to their annual revenue. Recently, the types of projects in which company $\mathrm{X}$ is involved have included: 
housing and hi-tech buildings, infrastructure, and mass transit projects both in Latvia and abroad. Primarily company X produces storage house buildings, industrial halls and large store buildings. The buildings consist of load-bearing steel construction and are closed with metal roof and facade elements. In addition to the construction projects, the company also manufactures roof and facade elements for the market. The Company X has certified quality management system (ISO 9000) and environmental management system (ISO 14001).

The research problem originates from everyday activities of the company, which is trying to improve project progress tracking and resource management in multi-project environment. This resulted in an $\mathrm{R} \& \mathrm{D}$ project, which includes work process analysis, synthesis of common information needs for all building design and construction processes and development of data transformations needed to overcome the identified gaps in the flow of information.

The work processes at the company can be divided into three groups - (1) architectural and detailed design, (2) prefabrication and (3) construction site activities connected with installation of elements. Designer takes input from customer requirements and develops architectural and detailed design. It is the basis for manufacturing and it also produces blueprints for construction. The work is well supported by CAD tools for both loadbearing construction design and facade elements design. Prefabrication is organized as mass production and is highly automated. Company $\mathrm{X}$ also produces and realizes steel roof, facade etc. elements ordered by individuals for private houses building. Industrialized production of building elements is integrated with other business activities such as sales, purchasing and logistics via the enterprise information system composed of several different programs. Construction site activities include organization and monitoring of the element's installation works.

Prefabrication and construction processes usually run in parallel, which is why close coordination between these two groups of activities is needed. At the construction site, costly delays can occur if the manufacturing plant does not provide building elements on time. On the other hand, early production of building elements when they are not needed increases the cost of storage. It makes on site material manipulation more complex and seriously affects other projects in a multi-project environment.

Historically, Company X had maintained different information systems for different business functions such as accounting, production, marketing, purchasing, etc. These legacy systems had it own methods and systems of collecting and storing information based upon it needs. Although these systems enabled managers to improve decision making within a specific functional area, these systems lacked functional integration and made communication and cooperation among business functions exceedingly difficult. Consequently, a company as a whole is loosing its competitive edges because it is not able to realize its full potential.

Company $\mathrm{X}$ had developed several single-functionality programs to facilitate independent management. For instance, for architectural and detailed design personnel use AutoCad program. A construction information system was developed to collect company information and it was based on FoxPro programming language. Despite being out of date, the systems were able to meet the basic requirements of conventional construction management style. Owing to the need to provide more real and accurate information for both top management staff and project clients, company X decided to evaluate whether it was necessary to implement an ERP system to enhance its IT competence. 
During 2007 Company X initiated a 2-month evaluation study to look at the possibility to introduce an ERP system. Employees were kept well-informed during this evaluation period and were encouraged to comment on the initiative. Finally the system selected was iScala, because of this system using in other represantativs in other countries. Once the decision to adopt was made, a central ERP manufacturing team was formed comprising 4 divisional representatives from Company $\mathrm{X}$ and two IT consultants from parent company, as well as 3 external consultants. This group partly had worked together before. The team was co-located in an office area at the Company X in Latvia. Those selected for the team were generally the individuals within a particular division who were most knowledgeable about ERP systems, having attended professional events about such systems, and having been involved in the evaluation discussions.

\subsection{The components of ERP system}

ERP begins with the identification of a customer objective or targeted goal for an implementation. The implementation may be the result of a new technology choice, reengineering the business, organizational restructuring, improving operations, or vertical integration. The definition of the objective allows ERP to identify the relevant process areas in which the business wants to gain greater value. ERP offers the following business process areas under which customer requirements can be related - enterprise planning, product development and marketing, asset management, organization and personnel, procurement logistics, production logistics, revenue and cost controlling, and external accounting.

The components of an ERP system are:

- ERP Software - Module based ERP software is the core of an ERP system. Each software module automates business activities of a functional area within an organization. Common ERP software modules include product planning, parts purchasing, inventory control, product distribution, order tracking, finance, accounting and human resources aspects of an organization.

- Hardware and Operating Systems - Many large ERP systems are UNIX based. Windows NT and Linux are other popular operating systems to run ERP software. Legacy ERP systems may use other operating systems.

- Business Processes - Business processes within an organization fall into three levels - strategic planning, management control and operational control. ERP has been promoted as solutions for supporting or streamlining business processes at all levels.

- ERP Users - The users of ERP systems are employees of the organization at all levels, from workers, supervisors, mid-level managers to executives.

In an ERP environment, two stakeholders generally participate in the implementation process: an internal project team to define the needs and an external contractor to provide a system to satisfy the requirements.

As depicted in Figure 1 in Company X, a project team consists of key users. During the implementation process, key users communicate with the contractors and learn system functionality and uses. Once the ERP system has been implemented, the key users then train end users. Key users and end users both interact directly with the ERP system. The external 


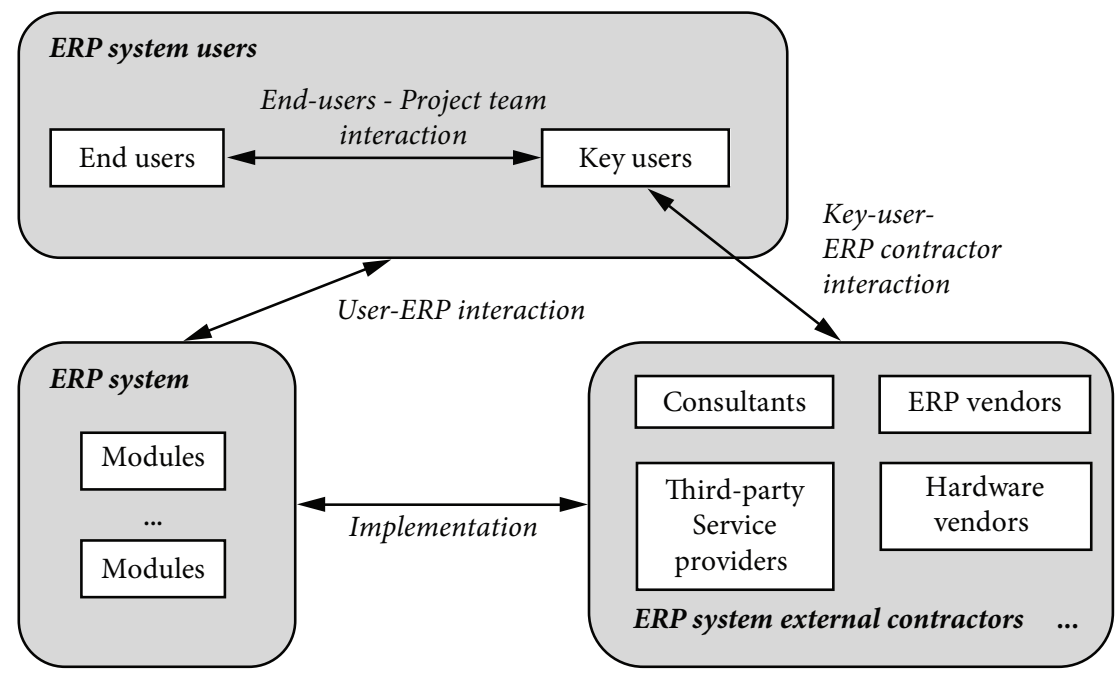

Fig. 1. The ERP system implementation stakeholders in Company $\mathrm{X}$

contractors may need to employ consultants, vendors, and third parties. The consultants communicate with key users to establish the acquiring organization's standard operating procedures and identify differences between the organization's business requirements and the functionality provided by the ERP system. The vendors and third parties may provide solution, design, or customization support according to standard operating procedures specifications, install the ERP system, and provide training to key users.

User acceptance is a key factor of ERP system implementation (Singh, Wesson 2009; Woo 2007) and consequently, its success (Vathanophas 2007). The organization should adopt an implementation process that may lead to user acceptance.

\subsection{ERP evaluation process}

Usually before implementing an ERP system, company develops a four-phase implementation plan to obtain desired information and to make necessary decisions, which are beneficial to its ERP implementation:

1. Self evaluation of the feasibility of ERP implementation.

2. Request for Proposal (RFP) preparation.

3. ERP systems evaluation.

4. ERP contract negotiation.

Some substantial issues in each using phase are depicted below.

To evaluate the feasibility of ERP implementation, company $\mathrm{X}$ formed a project team to deal with the affairs of ERP implementation. The project team included four members: one project manager, who is an IT department manager, three company staffs (from accounting, production and sales departments) and one outsourcing vendor. 
Before preparing the RFP, company X invited iScala ERP vendor to demonstrate this system and to provide system functionalities and requirements, as well as to adopt company lists and preliminary quotations. Simultaneously, company X conducted a self inspection program for collecting the requirement information on ERP implementation. The self inspection program gathered basic ERP requirements of all departments, depicted the current working processes of all departments, and assembled the working processes and ERP requirements according to a centralized management perspective.

Based on the results of the self inspection program and the data provided by ERP vendor, the project team generated a description that consisted of the work scope of the required ERP system, as well as the major ERP functionalities including preliminary sub functions, and relative schedule and preliminary ERP implementation contract.

Finally, company X signed four contracts with the implementation consultant, IT hardware vendor and two software vendors, i.e. Microsoft Corporation for MS Server 2003, SQL and terminal licenses, and EPICOR company, i.e. iScala representative in Latvia.

The implementation consultant needs to find a construction domain consultant with IT implementation experience to help in resolving the problems of implementing a general purpose ERP system for the construction domain and performing construction domain specified customizations. As a construction domain consultant was an IT manager from Lithuania, who helped to implement the same system two years ago.

\subsection{ERP implementation process and current status}

In the ERP implementation proposal prepared by the project team, the estimated duration of the implementation project is about 6 months, and can be divided into three phases. During the first phase the core system (the ERP infrastructure which consists of system hardware and software) of ERP is implemented. During the second phase of ERP implementation, a construction site information system integrated with the core ERP system is implemented. During the third phase the functionality customization of human resources and accounting management systems of ERP is completed.

The implementation project was initiated on June 2007, and the project team was established on September 2007. The project team surveyed available ERP software and conducted RFP preparation for about 1 month. During October 2007, the implementation contract was awarded to an ERP implementation consultant. The contract negotiations lasted about 2 weeks. Therefore, the ERP implementation project began in November 2007. Whereas the difference between the planned schedule and actual schedule concerning system evaluation and contract negotiation was about 2 months, the implementation duration was extended from 6 to 8 months. The causes of the delay in the ERP implementation schedule were summarized as follows:

1. Company $\mathrm{X}$ has no experience with large scale IT implementation. Top management thus needs to carefully consider all evaluation results of the consultant and the task force provided. This decision making style wasted some implementation time. 
2. Integrating the ideas and opinions of involved staff is challenging. All project team's members came from different departments. This inconsistency in the thinking of project team's members also delayed the implementation schedule.

3. A perfect implementation project is difficult to prepare. From the outset, some of the business processes of $\mathrm{X}$ have been described incorrectly, but some processes were not described. In addition, vendor did not properly understand some of the processes. Due to the fact that the vendor has already had experience in such projects, some of the emerging problems were solved immediately. As the implementation project proceeded, new information emerged. Some of the new ideas were put into the implementation project by some consultation meetings with the staff of company $\mathrm{X}$, but some not. This unexpected change delayed the schedule to some extent. The task of education training was completed. Up to now the project is successfully completed.

\subsection{The benefits of ERP system}

In any discussion on implementing an ERP system, the question "What are the benefits of an ERP System?" appears early in most selection cycles. Through the use of the implemented ERP system the Company X obtained the following results:

- Enhanced company operation through streamlining, improving and controlling business processes of major importance such as procurement, customer offers, customer complaints, equipment maintenance, marketing campaigns and others.

- Significant cost-reductions and time-savings in all the above mentioned business processes.

- Ability to manage service related personnel and related costs through the use of the resource management module of the system. In the past, the company could allocate only the productive resources' (workers and construction site related costs) cost to each company activity. Now by taking advantage of the resource management (timesheets) module of the system, the enterprise is able to manage the cost of the service personnel (engineering, R\&D departments, etc.) involved.

- Upgraded use of the company's already operating quality management system, which was not supported by an information system. The use of the proposed ERP system enabled the enterprise to avoid much paperwork, to reduce personnel's occupation times with quality management issues and to provide report insight to the management.

- Flexible and efficient production planning by implementing the manufacturing management (scheduling) module of the system. Project delivery times and idle times were reduced significantly, productivity was raised, more precies delivery time assessment incurred stock level minimization and customer satisfaction improved.

- Facilitated communication and data transfer of critical information for the whole enterprise. Now employees have instant access to real-time data, documents and reports that concern their duties. View of information flow is fully customized according to each user position. 
- Finally, the company exploited the abilities to control sales and promotion activities through the system, received quantitative data about the results of each promotion technique and managed to increase sales department efficiency.

Here are some areas to look for possible ROI and cost saving:

- Reduce Inventory through better visibility and efficiency.

- Savings through the reduction in duplicated efforts.

- More efficient operations allowing for increase in ability to process transactions (added capacity).

- Reduction in non-value added activities (lean processing).

- Higher utilization of employees (less transactional, more analytical).

- Improvement in decision making through more accurate and real-time data.

\subsection{Costs of the ERP system}

Based on the ERP survey conducted by Meta Group in 2002, the average cost of ERP ownership was a $\$ 15$ millions ranging from half millions to $\$ 300$ millions. The average cost per user per year could be as high as $\$ 20,000$. One of the most often-cited studies of the total cost of ownership (TCO) of ERP was completed by Meta Group in 2002 (Gartner acquired Meta Group in 2005). This TCO study accounted for hardware, software, professional services and internal staff costs. Costs included initial installation and the two year period that followed, which is when the real costs of maintaining, upgrading and optimizing the system for your business are felt. Among the 63 companies surveyed-including small, medium and large companies in a range of industries - the average TCO was $\$ 15$ million (the highest was $\$ 300$ million and lowest was $\$ 400,000$ ). While it's hard to draw a solid number from that kind of range of companies and ERP efforts, Meta came up with one statistic that proves that ERP is expensive no matter what kind of company is using it. The TCO for a "heads-down" user over that period was a staggering $\$ 53,320$ (Wailgum 2009).

Results from a 2007 Aberdeen Group survey of more than 1,680 manufacturing companies of all sizes found a correlation between the size of an ERP deployment and the total costs. Therefore, "as a company grows, the number of users goes up, along with the total cost of software and services", states the Aberdeen report. For example, a company with less than $\$ 50$ million in revenue should expect to pay an average of $\$ 384,295$ in total ERP costs, according to the survey results. A mid-market company with $\$ 50$ million to $\$ 100$ million in revenues can expect to pay (on average) just over a $\$ 1$ million in total costs; a much bigger mid-market company, with $\$ 500$ million to $\$ 1$ billion in revenues, should expect to pay just over $\$ 3$ million in total costs. And those companies with more than $\$ 1$ billion in revenues can expect to pay, on average, nearly $\$ 6$ million in total ERP costs (Wailgum 2009).

Most organisations do not understand the costs associated with an ERP system when they first commence the implementation. Poor cost estimation and scheduling leading to over budgeting and delayed implementation of ERP (Lindley et al. 2008; Francoise et al. 2009).

Chang and Lee (2011) study made explicit that project cost and schedule information should be the focus and the prime need for the construction ERP, by comparing the characteristics of 
manufacturing and construction as well as analyzing the project-based construction business. A cost/schedule information system and four processes were established.

Author summarized ERP implementation costs from the Company X results. The total cost of ERP ownership includes the costs of packaged software, hardware, professional services (for ongoing maintenance, upgrades and optimization) and internal costs (see in Table 1).

Table 1. ERP implementation costs

\begin{tabular}{|c|c|}
\hline Costs & Description \\
\hline $\begin{array}{l}\text { Costs of } \\
\text { Software }\end{array}$ & $\begin{array}{l}\text { The cost of packaged ERP software depends on the scope of implementation (the } \\
\text { number of ERP modules and the number of end users), complexity of software and } \\
\text { ERP vendors. ERP software that involves the integration with external business enti- } \\
\text { ties generally costs more. }\end{array}$ \\
\hline $\begin{array}{l}\text { Costs of } \\
\text { Hardware }\end{array}$ & $\begin{array}{l}\text { Implementation of ERP systems routinely requires purchase of new computer hard- } \\
\text { ware, systems software, network equipment and security software. The cost of hardware } \\
\text { varies in a wide range dependent on the scope of implementation and platforms. }\end{array}$ \\
\hline \multicolumn{2}{|c|}{ Costs of Professional Services } \\
\hline Customization & $\begin{array}{l}\text { The big chunk of costs of Professional Services is customization. The cost of customiza- } \\
\text { tion can easily out-run the cost of packaged ERP software, but it is the customization } \\
\text { of ERP software that makes an ERP a success or a failure. }\end{array}$ \\
\hline Integration & $\begin{array}{l}\text { ERP systems won't demonstrate its full potentials unless they are properly integrated } \\
\text { with other enterprise software application: } \\
\text { 1) the integration of various functional ERP modules, } \\
\text { 2) the integration of ERP with other e-business software applications, and } \\
\text { 3) the integration of ERP with legacy systems. }\end{array}$ \\
\hline $\begin{array}{l}\text { Data } \\
\text { Conversion }\end{array}$ & $\begin{array}{l}\text { The cost of data conversion depends on the format and the media that store the his- } \\
\text { torical data. Data conversion from legacy systems to relational database management } \\
\text { system is a time-consuming process. Data conversion may lead to further data gather- } \\
\text { ing to fill the missing links in data requirements. }\end{array}$ \\
\hline Testing & $\begin{array}{l}\text { ERP systems are thoroughly tested before they go into production. ERP testing in- } \\
\text { cludes unit testing, component testing, regression testing, performance testing and } \\
\text { user acceptance testing. }\end{array}$ \\
\hline Training & $\begin{array}{l}\text { Workflow and user interface design in ERP software are more complex than average } \\
\text { business software. ERP training is expensive because workers almost invariably have } \\
\text { to learn a new set of processes of doing their daily tasks besides learning how to use } \\
\text { the ERP software. To reduce the cost of ERP training and to ease the transitions from } \\
\text { old processes to new, organizations often seek the help from training companies which } \\
\text { are specialized in coaching workers on using ERP software from particular vendors. }\end{array}$ \\
\hline
\end{tabular}

\section{Conclusions}

ERP systems have a vital role in today's organizations to realize their vision and strategies. Implementations of ERP systems are one of the most difficult investment projects because of large number of problems, particularly related to cost, customization, and integration with existing systems. ERP has long been applied and promoted in the manufacturing industry. The construction industry has been slow in implementing ERP. In Latvia, the main difficulties 
for general contractors in applying ERP are the complexities of their working processes and habits. This research studied a case which described the selection of an ERP system by a local manufacturing and construction company in Latvia. This case study discussed some aspects of factors that influenced successful ERP implementation, it benefits and costs.

Successful ERP system implementation depends on effective project management principles. Firms implementing or considering implementing an ERP system or any system that attempts to integrate internal functions with planning and execution activities of both customers and vendors are at risk if they do not understand basic project management fundamentals. Top management support is very invaluable in ensuring that ERP projects come to fruition. This support might include providing strategic direction by being actively involved in various high-level cross-functional implementation teams. The top management support factor has next to the strongest correlation to ERP implementation of all the other factors identified.

Implementation of an ERP system is not a matter of changing the hardware or software systems, instead it entails transforming the company to a higher level of performance through a streamlined business process. When carefully conceived and successfully executed, ERP systems can changed the way companies conduct business for the better. Identification of these critical factors permits managers to obtain a better understanding of issues surrounding ERP implementation. This study provides insights to companies who are either embarking on ERP implementation or considering implementing ERP systems.

The analysis of the case study demonstrates that ERP system vendors have to work with manufacturing and construction industry professionals to improve more customized solutions for manufacturing and construction firms. That would be the best solution for implementing ERP in this industry. The ERP system can provide a general working environment for an enterprise to integrate its major business management functions by enabling automatic data communication among applications, integrated database management system, connection of the organizational network systems of business partners, and task automation. This translates into money saved on labor and productivity. The research findings suggest that the implementation of ERP can provide substantial benefits.

Successful implementation of ERP mandates continuous monitoring and selfdiagnosis throughout the implementation process. The major contributions of this study can be summarized as follows:

- ERP implementation should not be viewed as just an IT solution but as a system that would transform the company into a more efficient and effective organization. Emphasis on IT infrastructure was the least correlated factor to successful ERP implementation.

- Successful implementation of ERP is intricately tied to top management setting the strategic direction of the implementation process. This factor correlates the highest with ERP implementation among all the factors identified in the study. This is accomplished by a continuous support and monitoring of the implementation process.

- Sound and thorough understanding of project management principles and its application is critically linked to successful ERP implementation.

This is accomplished by establishing the scope of the project, establishing the project team and their responsibilities with clear statement of work, and defining the performance objectives. The project management factor correlates very strongly with successful ERP implementation. 


\section{Limitations of the study}

First, the results obtained from this study may not be generalizable considering the size of the sample; however, the results provide valuable insights for managers and executives associated with ERP implementation.

Second, the use of perceptual measures of ERP implementation success, although a common practice in the literature is highly subjective and lacks the credibility of hard data. More quantifiable measures such as actual versus projected implementation time, actual versus projected cost of implementation, operational efficiencies such as cycle time reduction, return on investment on the ERP project, and increased market revenue would have provided a better understanding of ERP implementation success.

\section{References}

Acikalin, U.; Kuruoglu, M.; Isikdag, U.; Underwood, J. 2009. Evaluating the integrative function of ERP systems used within the construction industry, in Zarli, A.; Scherer, R. (Eds.). Ework and Ebusiness in Architecture, Engineering and Construction. London: Taylor \& Francis Group, 245-254.

Adam, F.; O’Doherty, P. 2000. Lessons from enterprise resource planning implementations in Ireland toward smaller and shorter ERP projects, Journal of Information Technology 15(4): 305-316. http://dx.doi.org/10.1080/02683960010008953

Ahitur, N.; Neumann, S.; Zviran, M. 2002. A system development methodology for ERP systems, Journal of Computer Information Systems: 56-67.

Anne, P.; Shanks, G. 2002. A model of ERP project implementation, Journal of Information Technology 15(4): 289-303.

Back, W. E.; Bell, L. C. 1995. Quantifying process benefits of electronic data management technologies, ASCE Journal of Construction Engineering and Management 121(4): 415-421. http://dx.doi.org/10.1061/(ASCE)0733-9364(1995)121:4(415)

Bell, L. C.; Stukhart, G. 1986. Attributes of materials management systems, ASCE Journal of Construction Engineering and Management 112(1): 14-21. http://dx.doi.org/10.1061/(ASCE)0733-9364(1986)112:1(14)

Chang, H. 2002. A model of computerization of manufacturing systems: an international study, Information and Management 39: 605-624. http://dx.doi.org/10.1016/S0378-7206(01)00118-5

Chiara, F. 2001. Predicting the implementation effort of ERP projects: empirical evidence on SAP/R3, Journal of Information Technology 16(1): 33-48. http://dx.doi.org/10.1080/02683960010035943

Chung, B.; Skibniewski, M. J.; Kwak, Y. H. 2009. Developing ERP systems success model for the construction industry, Journal of Construction Engineering and Management 135(3): 207-216. http://dx.doi.org/10.1061/(ASCE)0733-9364(2009)135:3(207)

Chung, B. Y.; Skibniewski, M. J.; Lucas, H. C.; Kwak, Y. H. 2008. Analyzing enterprise resource planning system implementation success factors in the engineering-construction industry, Journal of Computing in Civil Engineering 22(6):373-382. http://dx.doi.org/10.1061/(ASCE)0887-3801(2008)22:6(373)

Davenport, T. H. 2000. Mission Critical: Realizing the Promise of Enterprise Systems. Boston, MA: Harvard Business School Press.

Dorien, J.; Malcolm, L. W. 2000. Asecond wind for ERP, The McKinsey Quarterly 2: 100-107.

Dowlatshahi, S. 2005. Strategic success factors in enterprise resource- planning design and implementation: a case-study approach, International Journal of Production Research 43(18): 3745-3771. http://dx.doi.org/10.1080/00207540500140864 
Ehie, I.; Madsen, M. 2005. Identifying critical issues in enterprise resource planning (ERP) implementation, Computers in Industry 56(6): 545-557. http://dx.doi.org/10.1016/j.compind.2005.02.006

Everdingen, J.; Hillegersberg, J.; Waarts, E. 2000. ERP adoption bu European midsize companies, Communications of the ACM 43(4): 27-31. http://dx.doi.org/10.1145/332051.332064

Francoise, O.; Bourgault, M.; Pellerin, R. 2009. ERP implementation through critical success factors' management, Business Process Management Journal 15(3): 371-394.

Fryer, B. 1999. The ROI challenge: can you produce a positive return on investment from ERP, CFO Magazine 15(9). New York, N.Y.

Huang, K. K.; Kim, Y. G. 2002. The critical success factors for ERP implementation: an organizational fit perspective, Information and Management 40(1): 25-40. http://dx.doi.org/10.1016/S0378-7206(01)00134-3

Huang, S. M.; Irene, S. Y.; Hung, Y. C. 2001. Planning enterprise resources by use of a reengineering approach to build a global logistics management system, Industrial Management and Data Systems 101(9): 483-491. http://dx.doi.org/10.1108/02635570110410672

Kim, Y.; Lee, Z.; Gosain, S. 2005. Impediments to successful ERP implementation process, Business Process Management Journal 11(2): 158-170. http://dx.doi.org/10.1108/14637150510591156

Klos, S.; Krebs, I. 2008. Methodology of ERP system implementation - a case study of project-driven enterprise, in International Conference 20th EURO Mini Conference "Continuous Optimization and Knowledge-Based Technologies" (EurOPT-2008), 405-409.

Krumbholz, M.; Galliers, J.; Coulianos, N.; Maiden, N. A. M. 2000. Implementing enterprise resource planning packages in different corporate and national cultures, Journal of Information Technology 15(4): 267-269. http://dx.doi.org/10.1080/02683960010008962

Lindley, T. J.; Topping, S.; Lindley, T. L. 2008. The hidden financial costs of ERP software, Journal of Managerial Finance 34(2): 78-90. http://dx.doi.org/10.1108/03074350810841277

Loh, T. C.; Koh, S. C. L. 2004. Critical elements for a successful ERP implementation in SMEs, International Journal of Production Research 42(17): 3433-345. http://dx.doi.org/10.1080/00207540410001671679

Mark, K.; Van Han, D. 2000. Enterprise resource planning: ERP system migrations, Communications of the ACM 43(4): 53-56. http://dx.doi.org/10.1145/332051.332072

Markus, M. L.; Axline, S.; Petrie, D.; Tanis, C. 2000. Learning from adopters' experiences with ERP: problems encountered and success achieved, Journal of Information Technology 15(4): 245-266. http://dx.doi.org/10.1080/02683960010008944

Monk, E.; Wagner, B. 2009. Concepts in Enterprise Resource Planning. 3rd ed. United States: Course Technology Cengage Learning.

Motwani, J.; Mirchandani, D.; Madan, M.; Gunasekaran, A. 2002. Successfiil implementation of ERP projects: 37. Evidence from two case studies, International Journal of Production and Economics 75(1): 83-96. http://dx.doi.org/10.1016/S0925-5273(01)00183-9

Nieuwenhuyse, I. Van; De Boeck, L.; Lambrecht, M.; Vandaele, J. N. 2011. Advanced resource planning as a decision support module for ERP, Computers in Industry 62: 1-8. http://dx.doi.org/10.1016/j.compind.2010.05.017

O'Leary, D. 2000. Enterprise Resource Planning Systems. Cambridge, UK: Cambridge University Press.

Olhager, J.; Selldin, E. 2003. Enterprise resource planning survey of Swedish manufacturing firms, European Journal of Operational Research 146: 365-373. http://dx.doi.org/10.1016/S0377-2217(02)00555-6

Rajagopal, P. 2002. An innovation-diffusion view of implementation of enterprise resource planning (ERP) systems and development of research model, Information and Management 40: 87-114. http://dx.doi.org/10.1016/S0378-7206(01)00135-5

Sarker, S.; Lee, A. S. 2003. Using a case study to test the role of three key social enablers in ERP implementation, Information and Management 40(8): 813-829. http://dx.doi.org/10.1016/S0378-7206(02)00103-9 
Scheer, A. W.; Frank, H. 2000. Enterprise resource planning: making ERP a success, Communications of the ACM 43(4): 57-61. http://dx.doi.org/10.1145/332051.332073

Singh, A.; Wesson, J. 2009. Evaluation criteria for assessing the usability of ERP systems, in ACM International Conference Proceedings of the 2009 Annual Research Conference of the South African Institute of Computer Scientists and Information Technologists. South Africa, 87-95.

Shi, J. J.; Halpin, D. W. 2003. Enterprise resource planning for construction business management, Journal of Construction Engineering and Management 129(2): 214-221. http://dx.doi.org/10.1061/(ASCE)0733-9364(2003)129:2(214)

Soja, P. 2006. Success factors in ERP systems implementations: lessons from practice, Journal of Enterprise Information Management 19(4): 418-433. http://dx.doi.org/10.1108/17410390610678331

Subramoniam, M.; Tounsi, M. 2009. An object oriented intelligent environment for ERP systems, Business Process Management Journal 15(1): 109-118. http://dx.doi.org/10.1108/14637150910931497

Sun, A.; Yazdani, A.; Overend, J. 2005. Achievement assessment for enterprise resource planning (ERP) system implementations based on critical success factors (CSFs), International Journal of Production Economics 98(2): 189-203. http://dx.doi.org/10.1016/j.ijpe.2004.05.013

Tsai, W.-H.; Lee, P.-L.; Shen, Y.-S.; Lin, H.-L. 2012. A comprehensive study of the relationship between enterprise resource planning selection criteria and enterprise resource planning system success, Information and Management 49(1):36-46. http://dx.doi.org/10.1016/j.im.2011.09.007

Umble, E. J.; Umble, M. M. 2002. Avoiding ERP implementation failure, Industrial Management (January / February): 25-33.

Verville, J.; Bernadas, C.; Halingten, A. 2005. So you're thinking of buying an ERP? Ten critical factors for successful acquisitions, Journal of Enterprise Information Management 18(6): 665-677. http://dx.doi.org/10.1108/17410390510628373

Verville, J.; Palanisamy, C. B.; Halingten, A. 2007. ERP acquisition planning: a critical dimension for making the right choice, Long Range Planning 40: 45-63. http://dx.doi.org/10.1016/j.lrp.2007.02.002

Vathanophas, V. 2007. Business process approach towards an inter-organizational enterprise system, Business Process Management Journal 13(3): 433-450. http://dx.doi.org/10.1108/14637150710752335

Voordijk, H.; Leuven, A. V.; Laan, A. 2003. Enterprise resource planning in a large construction firm: implementation analysis, Construction Management and Economics 21(5): 511-521. http://dx.doi.org/10.1080/0144619032000072155

Wailgum, T. 2009. Enterprise Resource Planning. CIO [online], [cited 29 July 2009]. Available from Internet: http://www.cio.in/strategy-guide/enterprise-resource-planning-erp

Woo, H. 2007. Critical success factors for implementing ERP: the case of a Chinese electronics manufacturer, Journal of Manufacturing Technology Management 18(4): 431-442. http://dx.doi.org/10.1108/17410380710743798

Wood, B. 2010. SAP ERP Project Failures Lessons Learned and Mini Case Studies 3 [online], [cited 13 June 2010]. Available from Internet: http://www.r3now.com/tag/erp-critical-success-factor

Yang, J.-B.; Wu, Ch.-T.; Tsai, Ch.-H. 2007. Selection of an ERP system for a construction firm in Taiwan: a case study, Automation in Construction 16: 787-796.

http://dx.doi.org/10.1016/j.autcon.2007.02.001

Andrejs TAMBOVCEVS. PhD student, Faculty of Computer Science and Information Technology, Riga Technical University, Latvia. Riga Technical University Engineer degree (1992). Riga Technical University Master degree in Scientific Engineering (1995), Riga Technical University Bachelor degree in Economics (1999). A participant of research projects financed by EU. Author of 9 scientific articles and author/coauthor 2 training books. Research interests: information management and technology, Enterprise resource planning systems, logistic information systems, decision support systems. 